\title{
PENGGUNAAN INTERNET OLEH DOSEN BERDASAR GENDER DAN GENERASI
}

\author{
Rina Sari Kusuma \\ Program Studi Ilmu Komunikasi \\ Universitas Muhammadiyah Surakarta \\ Email : rinasari.kusuma@ums.ac.id
}

\begin{abstract}
The usage of internet in higher education is increasing. This system is being implemented for efficiency and effectivity of communication and activity monitoring among the academicians. On the other hand, not all academicians have the exact same technology literacy. Muhammadiyah University of Surakarta is one of top university in Indonesia that already use many internet based programmes in their academic and administration activities. The purpose of this research see how the role of gender and generation affect the internet usage of academicians in UMS. Internet usage pattern covers items such as knowledge and experience on the internet, purpose of using internet, and frequency of using e-mail. The result shows that generation become the main factor that influence the pattern and optimalization usage of the internet than the gender one. Academicians that belong to Generation $Y$ or milineal is the generation that has the highest potential of maximalize the internet technology, especially for academic activity.
\end{abstract}

Keywords: Internet, Gender, Generation, Academician

\section{A. PENDAHULUAN}

Menggabungkan teknologi, informasi, dan komunikasi dalam pengajaran dan pembelajaran di pendidikan tinggi telah menjadi isu penting. Dalam dunia akademik, penggunaan internet tidak terbantahkan lagi. Terdapat peningkatan penggunaan teknologi komunikasi dalam dunia pendidikan (Li, 2007). Beberapa tahun terakhir, lingkungan kerja tidak lagi dibatasi oleh ruang dan waktu. Pekerjaan dapat dilakukan dimana dan kapan saja selama ada koneksi internet. Hal ini berdampak pada cara informasi dibagikan, diterima, dan dikonsumsi. Tidak diragukan lagi, internet telah menjadi alat paling efektif tidak saja dalam proses komunikasi melainkan sharing ideas.

Sejarah internet diawali pada tahun 1960an ketika beberapa ilmuwan komputer dipekerjakan oleh Pentagon untuk membangun sebuah sistem desentralisasi jaringan komunikasi. Sebagai sebuah alat untuk menyimpan, mengirim, dan mendistribusikan informasi antar komputer dan penggunanya, internet telah mengubah komputer biasa menjadi sumber yang berkoneksi kuat (a powerful connecter resources) (Selwyn, Gorard, Furlong, 2005). Berjalannya waktu jaringan tersebut berkembang dengan cepat untuk menghubungkan banyak universitas, pusat penelitian begitu juga dengan organisasi komersial (Munusamy, 2009).

Ketidaksetaraan offline (offline inequalities) seperti pendidikan dan gender tercermin pada cara seseorang menggunakan teknologi (Norris dalam Helsper, 2010). Beberapa decade terakhir, jumlah perempuan pengguna internet telah meningkat secara signifikan. Bukan sebuah kebetulan jika peningkatan pengguna internet perempuan berbarengan dengan diterimanya teknologi seperti e-mail dan web oleh masyarakat (Royal, 2007).

Internet memiliki dampak pada berbagai bidang, salah satunya adalah sistem pendidikan tinggi. Selain untuk 
pengembangan dan implementasi strategi mengajar inovatif yang baru, internet juga digunakan antar dosen untuk kegiatan akademis lainnya. Sebagai pengajar, dosen tidak hanya disibukkan dengan kegiatan mengajar melainkan juga kegiatan administrasi dan keuangan yang tidak jarang menguras waktu dan tenaga. Dalam penelitian mengenai efek internet dalam performa akademik dihasilkan bahwa penggunaan internet menjadi faktor utama dalam mempengaruhi performa akademik dan kehidupan sosial di universitas (Rizvi, 2010). Internet sebagai sebuah media baru menjadi kajian bagi peneliti bidang ilmu komunikasi khususnya, karena internet membuat kabur antara media komunikasi dan antarpribadi. Internet memiliki karakteristik perpaduan dari dua level komunikasi tersebut. Peneliti bidang ilmu komunikasi perlu untuk mengembangkan keilmuan yang lebih mendalam mengenai dinamika sosial dan individu dari penggunaan internet tersebut (Selwyn, Gorard, Furlong, 2005:222)

Sebagai sebuah universitas swasta terbesar di kota Surakarta, Universitas Muhammadiyah Surakarta (UMS) telah mengaplikasikan penggunaan internet di banyak bidang akademis antara lain: penggunaan email korporat (@ums.ac.id) untuk intensifikasi dan efisiensi komunikasi banyak arah, pengajuan rencana kegiatan dan anggaran (rpps.ums.ac.id), pengajuan proposal penelitian dan pembiayaan kegiatan dosen (rpid.ums.ac.id), pengajuan proposal LPPM dan pendanaan kegiatan akademis dosen (my.ums.ac.id) dan masih banyak lagi. Hal ini menjadikan UMS bergerak secara non konvensional ketika berhadapan dengan teknologi komunikasi. Hal-hal seperti: keterlambatan pengiriman surat atau pemberitahuan, dokumen penting yang tersesat atau hilang ketika dikirimkan melalui kurir menjadi minim. Batasan ruang dan waktu tidak lagi menjadi penghalang.

Dilain pihak, ada halyang perlu dicermati ketika mengaplikasikan sebuah sistem berbasis internet. Pengguna sistem tersebut yang didominasi dosen tidak semuanya memiliki pengetahuan dan pengalaman yang sama dalam berinternet. Faktor seperti usia, senioritas, status pernikahan, dan gender menjadi hal yang menarik untuk dilihat pengaruhnya terhadap pola penggunaan internet di dalam pekerjaan. Survey yang dilakukan oleh Selwyn, Gorard dan Furlong (2005) mengkonfirmasi bahwa seseorang menentukan apakah dirinya menggunakan internet dan untuk apa digunakan.

Penelitian terdahulu oleh Lazinger (Thanuskodi, 2013) dalam penelitiannya yang berjudul "Internet Use by Faculty Members in Various Disciplines: A Comparative Case Study" menunjukkan staf dari Fakultas Ilmu Pasti (science) dan Pertanian lebih tinggi menggunakan internet dibandingkan dengan Fakultas Humaniora dan IImu sosial. Penelitian ini dilakukan dengan menggumpulkan kuesioner yang dibagikan kepada anggota fakultas dari seluruh jurusan yang ada di Universitas Hebrew di Jerussalem. Penelitian serupa juga pernah dilakukan oleh Rajiv Kumar (Thanuskodi, 2013) yang berjudul "Internet and Its Use in the Engineering Colleges of Punjab, India: A Case Study" bertujuan untuk meneliti pengalaman dan frekuensi pengguna internet, waktu yang dihabiskan, lokasi dan tujuan penggunaan internet sampai masalah yang dihadapi oleh guru dan murid di kampus Teknik di Punjab. Lambatnya akses internet, kesulitan dalam mencari informasi yang relevan menjadi masalah utama yang dialami pengguna.

Dua penelitian di atas sama-sama berada di konteks pendidikan tinggi/ universitas dalam kaitannya dengan pola dan hambatan penggunaan internet. Namun, kedua penelitian tersebut tidak memasukkan faktor keunikan individu, misalnya status pernikahan maupun senioritas pekerjaan dalam analisisnya. Melalui penelitian ini, peneliti ingin melihat lebih jauh lagi mengenai pemahaman dan pengalaman dosen UMS, terutama berkaitan dengan generasis dan gender dalam menggunakan dan mengaplikasikan 
sistem berbasis internet dalam pekerjaan.

\section{Gender dan Konsumsi Internet}

Telah banyak penelitian yang berusaha melihat hubungan antara gender dan penggunaan internet. Kesenjangan mulai dari akses, konsumsi, pengetahuan, bahkan kepercayaan diri, menjadi highlight dari banyak penelitian tersebut. Faktor individu menjadi aspek yang signifikan dalam memahami akses dan penggunaan internet (Norris dalam Thanuskodi, 2013). Winker (Thanuskodi, 2013)juga menyebutkan masih terdapat perbedaan spesifik dari gender yang tidak dapat dijelaskan hanya dengan mempelajari perbedaan pendidikan dan bahkan pendapatan serta efeknya dalam penggunaan internet.

Akses internet oleh perempuan terus meningkat sejak pertama kali teknologi ini ditemukan. Pada awalnya, keikutsertaan perempuan dalam teknologi ini dibatasi. Pada tahun 1995 ketika penggunaan internet meningkat secara drastis, tidak banyak perempuan yang tertarik terhadapnya. Kemudian, seiring dengan tuntutan jaman dan perkembangan pola pikir masyarakat, perempuan mulai mengubah interaksinya dengan internet (Thanuskodi, 2013). Walaupun kesenjangan antara laki-laki dan perempuan tetap ada sampai sekarang, tapi jarak itu mulai berkurang. Data kuantiatif mengenai gender dan penggunaan internet menunjukkan tren mengenai peningkatan penggunaan internet oleh perempuan (Singh, 2001). Walaupun memang kebanyakan data tersebut ditemukan di dunia Barat (Li, 2007).

Kesenjangan ini ternyata tidak hanya berhenti pada hal yang terlihat dari luar. Masalah konsep diri juga ikut berperan dalam membangun kesenjangan. Nai Li (2007) menunjukkan kepercayaan diri menjadi faktor penghambat bagi perempuan untuk berpartisipasi lebih dalam penggunaan internet. Kepercayaan diri mengarah pada keinginan untuk lebih meng-eksplore pemahaman dan penggunaan internet. Perempuan dilihat lebih memiliki kepercayaan diri yang lebih rendah dibandingkan laki-laki dalam hal teknologi.

Masalah konsep diri pada akhirnya mempengaruhi ketrampilan atau keahlian berinternet untuk diasah lebih dalam lagi. Ketrampilan memiliki peran yang penting dalam membingkai kesenjangan gender dalam penggunaan internet. Ketrampilan dapat dilihat sebagai kemampuan pengguna (internet) untuk bisa memperoleh info/isi secara efektif dan efisien. Laki-laki dan perempuan akan secara signifikan membedakan perilaku mereka terhadap ketrampilan teknologi (Hargittai dan Shafer dalam Thanuskodi, 2013).

Ketidaknyamanan perempuan dengan teknologi ditemukan dalam penelitian Singh (2001) dalam penelitiannya mengenai "Gender and The Use of Internet at Home". Dalam penelitian di Australia tersebut, perempuan menggunakan internet di rumah sebagai alat untuk melakukan aktivitas, alih-alih untuk bermain atau menguasai teknologi. Perempuan melihat teknologi sebagai sesuatu hal yang bersifat maskulin, sehingga ketika akhirnya perempuan merasa nyaman dengan internet, hal tersebut disebabkan karena mereka melihatnya sebagai sebuah alat, bukan teknologi.

Walaupun internet sering dikarakterisasikan sebagai dominasi lakilaki, namun bukti terakhir menunjukkan kesenjangan gender tersebut menghilang dengan cepat (Weiser, 2004). Jika lebih banyak perempuan menggunakan internet, aplikasi dan konten yang mereka sukai, maka hal itu yang menbedakannya dengan preferensi laki-laki. Royal (2007) dalam penelitiannya yang berjudul "Framing the Internet: A Comparison of Gendered Space" menjelaskan ada dua jenis website berbasis laki-laki dan perempuan. Royal melihat teknologi (baca: internet) "beradaptasi" dalam menyajikan konten yang sesuai dengan masing-masing gender. Womencontent-web lebih menfokuskan pada rumah tangga dan keluarga, sedangkan Man-content-web lebih mengenai bisnis, hubungan, dan olahraga. 
Secara singkat dapat kita lihat bahwa internet tidak terlepaskan dari kehidupan keseharian kita terutama dalam lingkungan akademik. Namun, masih terdapat beberapa alasan mengapa laki-laki dan perempuan menggunakan internet secara berbeda dan bagaimana gender berperan dalam mempengaruhi pola penggunaan internet tersebut. Sehingga studi ini ingin melihat hal tersebut dalam konteks akademis pendidikan tinggi oleh dosen.

\section{Generasi dan Penggunaan Teknologi}

Perkembangan teknologi komunikasi telah mengambil alih dunia dalam segala tindakan yang dilakukan. Hal yang terlihat tidak mungkin dilakukan puluhan tahun lalu menjadi begitu mudah dilakukan sekarang. Faktor umur dari pengguna internet juga memiliki peran dalam memediasi perbedaan gender (Weiser, 2004). Tidak dapat dipungkiri bahwa generasi yang tumbuh bersama dengan teknologi memiliki ekpektasi dan pengalaman terhadap penggunaan media digital yang jauh berbeda dengan generasi sebelumnya (Thanuskodi, 2013).

Dunia kerja sekarang ini terdiri dari empat generasi yang dapat digolongkan sebagai berikut (PENN, 2008):

1. Tradisionalist (1922 - 1945)

Merupakan generasi yang memiliki sifat loyal, pekerja keras, dan etika kerja yang kuat. Orang yang berasal dari generasi ini adalah orang yang berorientasi pada team.

\section{Baby Boomers (1945 - 1964)}

Merupakan generasi yang dipandu oleh uang dan etika kerja serta loyal dan mau mengatur orang lain. Orang dari generasi ini melihat teknologi sebagai tantangan.

\section{Generation X (1965 - 1980)}

Merupakan generasi yang dipengaruhi oleh internet dan media. Orang yang berasal dari generasi ini kadang skeptis dan kesetiaan terbesar ada pada diri mereka. Mereka memiliki pengalaman dengan teknologi dan dapat belajar dengan cepat.

4. Generation $Y(1981$ - 1999)
Disebut juga sebagai Milineals atau Net Generation. Orang yang berasal dari generasi ini adalah orang yang realistis, percaya diri, dan pragmatik. Mereka memiliki pengalaman dengan teknologi dan bahkan mampu membantu orang lain untuk belajar. Generasi ini adalah generasi pertama yang mengenal sosial media dan sudah menggabungkan teknologi ke dalam kehidupan mereka.

Kesenjangan generasi adalah perbedaan nilai, gaya hidup, dan kesempatan ekonomi yang ada di antara orang yang berbeda umur yang hidup di masyarakat yang sama. Kesejangan antar generasi terjadi pada semua aspek kehidupan terutamanya teknologi. Satu generasi bisa jadi ahli digital (digital native) sedangkan yang lainnya adalah imigran atau alien/asing terhadap teknologi. Perbedaan generasi mengarah pada akses teknologi komunikasi dan informasi yang berbeda. Generasi yang lebih muda dianggap lebih dekat dengan internet, karena awal munculnya teknologi tersebut berkembang seiring dengan pertambahan umur mereka. Generasi yang lebih muda menunjukkan kesenjangan antara laki-laki dan perempuan dalam mengakses internet jauh lebih kecil dibandingkan dengan generasi yang lebih tua (Helsper, 2010: 1). Hal ini dibuktikan dalam penelitian Enochsson (2005) yang menunjukkan bahwa remaja laki-laki dan perempuan tidak begitu memiliki ketertarikan yang berbeda dalam praktik teknologi internet. Kesenjangan ini semakin mengecil dan aktivitas online seperti menggunakan internet dan mencari informasi dengan mesin pencari semakin meningkat yang dilakukan oleh seluruh generasi (Ramasubbu, 2015).

Perbedaan gender dapat digunakan untuk meramalkan kepada masyarakat akan informasi yang akan terbentuk di masa depan. Perempuan generasi tua yang jauh dan tidak familier dengan teknologi akan segera tergeser dengan kemampuan perempuan generasi sekarang yang memiliki ketrampilan teknologi hampir sama dengan laki-laki. Hal ini 
dibuktikan dengan adanya penelitian yang menunjukkan gender dan umur mengarah pada pengalaman penggunaan internet yang berbeda (Helsper, 2010: 3).

\section{B. METODOLOGI}

Penelitian ini adalah penelitian kualitatif yang bertujuan untuk mencari makna, pemahaman, pengertian mengenai sebuah fenomena/kejadian dengan terlibat langsung ataupun tidak langsung dalam setting yang diteliti yang berupa kontekstual dan menyeluruh (Yusuf, 2014). Dalam penelitian kualitatif, peneliti membangun sebuah gambaran yang kompleks, menyeluruh, menganalisa katakata, melaporkan pandangan detail dari informan, dan melakukan studi dalam setting alami (Creswell, 2009).

Individu manusia adalah unit analisis yang paling umum dalam penelitian sosial. Dalam norma generalized understanding dikatakan; temuan ilmiah yang paling berarti adalah jika dapat diaplikasikan untuk semua jenis orang. Namun, dalam praktiknya, studi yang ada dibatasi hanya pada orangorang yang hidup di daerah tertentu atau bekerja di perusahaan yang sama. Ada pula yang disebut sebagai circumscribed groups (Babbie, 1995) yaitu kelompok yang anggotanya menjadi unit analisis-pada level individu-murid, pekerja, orang tua, dan anggota fakultas.

Dalam penelitin ini, sumber datanya yakni dosen Universitas Muhammadiyah Surakarta Fakultas Ilmu Komunikasi dan Informatika. Fakultas ini dipilih karena menjadi satu-satunya fakultas yang memiliki Prodi Sosial dan Eksakta dalam satu payung. Selain itu, anggota fakultas ini dianggap berada lebih dekat dan familier dengan teknologi komunikasi dan informasi dibandingkan dengan fakultas lain.

Teknik sampling yang digunakan adalah purposive sampling. Peneliti memilih responden dengan alasan dan kriteria tertentu sesuai dengan tujuan peneliti. Responden yang dipilih didasarkan pada kriteria antara lain: dosen yang bekerja di UMS yang diambil dari masing-masing generasi yang terdiri atas laki-laki dan perempuan. Dikarenakan untuk generasi tradisionalis sudah sulit untuk menemukan dosen yang aktif bekerja, maka generasi yang dijadikan sampel hanya terdiri atas generasi Baby Boomers, $\mathrm{Y}$ dan $\mathrm{X}$ sejumlah 4 (empat) orang.

\section{HASIL ANALISA}

Tabel 1. Profil informan

\begin{tabular}{lll}
\hline $\begin{array}{c}\text { Responden } \\
\text { (Umur, tahun) }\end{array}$ & Gender & Generasi \\
\hline A $(51,1964)$ & Laki-laki & Baby Boomers \\
B $(41,1974)$ & Perempuan & Gen $X$ \\
C $(31,1984)$ & Laki-laki & Gen $Y$ \\
D $(31,1984)$ & Perempuan & Gen $Y$ \\
\hline
\end{tabular}

Penelitian ini menghasilkan enam macam kategori, yaitu: Pemahaman terhadap Internet, Pengalaman penggunaan Internet, Tujuan Penggunaan Internet, E-mail sebagai alat komunikasi, Program Akademik dan Administrasi berbasis Internet di UMS, dan Hambatan Penggunaan Internet di Kantor

\section{Pemahaman Terhadap Internet}

Informan diminta untuk mendeskripsikan persepsi dan pemahaman mereka mengenai internet. Umumnya semua informan mampu menjelaskan mengenai apa dan fungsi dari internet. Jawaban yang serupa mengarah pada fungsi internet sebagai alat komunikasi dan informasi untuk menghubungkan orang yang terpisah jarak, ruang, dan waktu. Hal ini dianggap penting bagi kehidupan dosen karena untuk melakukan kegiatan akademik mereka tidak selalu ada di suatu tempat yang sama.

Salah satu responden perempuan mampu memberikan deskripsi yang lebih mendalam mengenai bagaimana seharusnya kita memperlakukan informasi yang ada di internet. "..semua informasi di internet tidak bisa kita jadikan rujukan. Rujukan harus divalidasi lagi." Ungkapnya. Umumnya orang masih melihat yang ada di internet adalah sesuatu yang pasti kebenarannya. 
Pengguna internet jarang mempertanyakan dan mengkonfirmasi mengenai kredibilitas dari informasi tersebut. Hal ini juga dipahami oleh responden laki-laki dari generasi yang sama (Gen Y). "..yang perlu diwaspadai sekarang adalah banyak informasi yang berkembang yang sifatnya tidak bertanggung jawab atas informasi yang mereka buat."

Walaupun generasi $Y$ mampu melihat pentingnya validasi dari informasi, generasi Baby Boomers malah mampu mengkategorisasikan pengguna internet. "Pemakai internet dikategorikan dalam beberapa tipe, yaitu: pengguna media sosial, untuk mengentahui isu-isu mutakhir, untuk kepentingan kerja, dan untuk game."

Kedua gender di atas memiliki pengetahuan yang cukup mengenai internet. Studi sebelumnya menunjukkan internet tidak lagi merupakan alat yang bersifat maskulin. Dengan perkembangan teknologi seperti sekarang ini, internet tidak saja merupakan konsumsi kaum laki-laki. Kemampuan informan dalam mendeskripsikan apa itu internet seperti di atas menunjukkan bahwa mereka memiliki pengalaman yang tidak jauh berbeda dalam menggunakan internet. Sebagai generasi tertua, informasi Baby Boomers mampu mendeskripsikan mengenai macam dan tujuan pengguna menggunakan internet. Jadi bisa dilihat bahwa gender dan generasi tidak menjadi faktor penentu dalam pemahaman mereka mengenai internet.

\section{Pengalaman Penggunaan Internet}

Semua responden menunjukkan bahwa mereka memiliki paling tidak 10 (sepuluh) tahun pengalaman menggunakan internet. Hal ini sudah semestinya karena pekerjaan dosen mewajibkan mereka untuk familiar dengan penggunaan teknologi informasi dan komunikasi semacam internet. Dua dari keempat responden bahkan mengenal komputer jauh waktu mereka masih sekolah di SMA. Hal ini karena internet pada sekitar tahun 1999 sudah cukup banyak tersedia. "Dulu saya diajak teman saya, mungkin yang saya lakukan pada saat itu adalah membuat email. Saat itu di Slamet Riyadi ada tempat (warung internet) yang namanya Yahoo...". Responden yang lain justru baru menggunakannya ketika pertama kali masuk kerja. "Pertama kali menggunakan ketika masuk kerja (16 tahun), yaitu dengan dibuatkan email. Bila tidak mengerti maka tanya sama teman."

Data menunjukkan pengalaman menggunakan internet yang bervariasi. Pembedaan tidak terletak pada gender, melainkan pada generasi. Generasi $Y$ menggunakan internet pada usia yang lebih muda, sedangkan generasi Baby Boomers dan X pada saat mulai bekerja. Dalam poin ini, kedua gender menunjukkan kesamaan pada pengalaman penggunaan internet bila berasal dari generasi yang sama.

Generasi Baby Boomers dilihat sebagai generasi pertama yang berkenalan dengan komputer. Baginya, internet masih dilihat sebagai sesuatu yang baru. Hal ini berbeda dengan generasi $X$ (melek komputer) dan Y/ Milenial (ahli komputer dan internet) yang lahir dalam waktu teknologi ada di sekitar mereka (Rosen, 2015).

\section{Tujuan Penggunaan Internet}

Informan ditanya mengenai hal apa saja yang mereka lakukan dengan internet. Hampirsemuaresponden menggunakannya untuk tujuan yang bervariasi, dari urusan kantor, pribadi, hiburan, informasi, komunikasi, sampai bisnis. Bahkan salah satu responden dari generasi $X$ melihat kelancaran bisnis juga didukung dengan internet. "...kalo mengandalkan pekerjaan saya, kan (kita) ngga hidup".

Kebutuhan akan sosialisasi dengan orang lain ternyata menjadi hal yang wajib bagi mereka. Semua informan memiliki sosial media, seperti: Facebook dan Twitter. Walaupun demikian, dimilikinya akun sosial media tersebut dibarengi dengan keikutsertaan mereka di berbagai grup akademik di Facebook. Hal ini berguna untuk mereka sebagai dosen yang memerlukan jaringan dan informasi dari akademisi di lain instansi. 
Responden perempuan generasi $Y$ mengaku sering menggunakan internet untuk belanja online, sedangkan responden laki-laki lebih banyak mengakses situs akademik, seperti Scribd dan Akademia. edu. Kondisi ini sesuai dengan penelitian sebelumnya yang menunjukkan terdapat perbedaan tipe informasi yang dicari oleh laki-laki maupun perempuan.

\section{E-mail Sebagai Alat Komunikasi}

Ketika ditanya mengenai e-mail sebagai alat komunikasi utama dari internet, semua responden memiliki jawaban yang serupa. Semua responden kompak memiliki tiga akun email, yaitu: Yahoo Mail, Google Mail, dan email korporat UMS. Namun, hanya Gmail dan email korporat lah yang sering digunakan sehari-hari. Semua responden juga memiliki kesamaan dalam pembagian fungsi dari akun email yang mereka miliki. Untuk kepentingan pekerjaan sebagai dosen, email korporatlahyang sering mereka gunakan. Email korporat digunakan untuk alat komunikasi antar kolega di tingkatan prodi, fakultas, dan bahkan universitas. Oleh sebab itu, hampir semua isi inbox-nya adalah hal-hal yang berkaitan dengan akademik, seperti: informasi tentang akses jurnal luar negeri, pengumuman dosen berprestasi, informasi pelatihan jurnal, undangan rapat, dan bahkan tausyiah.

Responden perempuan generasi $Y$ menunjukkan kesadaran akan branding dari universitas ketika menggunakan email korporat. ".saya menghubungi dosen untuk urusan pekerjaan yang menyangkut masalah kedosesan menggunakan akun UMS. Dan urusan yang harus kita menampakkan dosen UMS itu saya pake domain UMS. Jadi misalkan siapa ngaku-ngaku dosen gitu kan ketahuan saya dosen UMS".

Walau demikian, kadang pesan di inbox email korporat sering tidak tepat sasaran. "Walaupun kadang salah sasaran, karena seringnya ditujukan pada jabatan tertentu (Dekan, Kaprodi, Kepala Unit, dan lain-lain) tapi semua staff dikirimi. Jadi kita yang misal dosen biasa, padahal informasi itu diberikan pada Kaprodi sama Dekan, kan kita jadi ga butuh gitu... tapi kita terpaksa nerima gitu kan.... ya seharusnya dikirimnya hanya ke Kaprodi, ke Dekan... Akibatnya email semacam itu dihapus semua".

Hampir seluruh responden membuka email secara rutin setiap hari, karena berkaitan dengan kegiatan dan komunikasi akademik antar dosen. Terkecuali responden Baby Boomer yang membuka email seminggu sekali. Baginya pembagian informasi menggunakan layanan pesan pendek (SMS) dianggap lebih efektif. "Tidak selalu mengecek email, mungkin seminggu sekali. Sehingga sering melewatkan informasi atau kegiatan. Kalau di ema-il tetap perlu diingatkan melalui sms. Sehingga tetap lebih efektif mengirimkan pesan melalui sms."

\section{Program Akademik dan Administrasi Ber- basis Internet di UMS}

Sebagai universitas yang selalu berusaha mengikuti perkembangan teknologi, UMS sudah memiliki beberapa program akademik dan administrasi berbasis internet. Program akademik semacam ADUMS dan ANUMS memang masih berbasis LAN. Sedangkan untuk program administrasi semacam Rencana Perkembangan Program Studi (RPPS) dan MyUms sudah dapat diakses dengan internet dari luar. Intinya program semacam ini ditujukan untuk efisiensi kelancaran pengajuan, monitoring, pelaporan, dan dokumentasi kegiatan akademik dan administrasi. Semua responden memiliki suara yang sama berkaitan dengan program ini. Program semacam ini dianggap memiliki kontribusi yang besar bagi kegiatan yang dilakukan dosen. "Program RPPS dan RPID dianggap mempermudah dan melancarkan pekerjaaan kantor karena tidak manual lagi. Program tersebut berguna untuk mengisi formulir ajuan dan mengecek proses ajuan keuangan dan administrasi". "Kontribusi penggunaan program antara lain: laporan penelitian terdata dan terekam serta mampu mengontrol dan ikut berpartisipasi proses kegiatan akademik prodi dan universitas". Dengan program tersebut pekerjaan secara online dapat diselesaikan dari rumah 
apalagi jika membutuhkan urgensitas yang tinggi di luar jam kerja.

Dari sisi operasionalisasinya, responden laki-lakigenerasiY melihattampilan program tergolong mudah, menarik, dan ada petunjuknya. Walaupun tidak semua orang mau membacanya. "Keribetan" membaca manual semacam ini yang membuat responden generasi Baby Boomer jarang menggunakannya. Sesuatu baru menjadi hal yang membutuhkan banyak tenaga untuk memahaminya. Alhasil responden laki-laki Baby Boomers sering meminta petunjuk instan yaitu dengan bertanya ke yang lebih muda. "..kalo yang sudah sepuh-sepuh gitu ya kadang-kadang minta tolong ke yang muda aja. Pada prinsipnya kalau orang mau baca petunjuknya ya selesai, kadang-kadang orang ga mau baca (petunjuk)." Familiaritas tampilan program ini ternyata tidak sepenuhnya disepakati oleh responden perempuan generasi Y. Dia mengatakan walaupun tidak ada kesulitan dari sisi teknis, namun tampilan menu kadang membingungkan, karena sering berubah kontennya. Menurutnya hal ini terjadi karena programnya sendiri masih belum matang.

Berbeda dengan temuan yang ada di poin sebelumnya, generasi Baby Boomer pada program akademik ini merasa tidak familiar dan memerlukan pembelajaran yang cukup membutuhkan tenaga. Walaupun demikian generasi Baby Boomer sadar bahwa lingkungan dia bekerja mewajibkan karyawannya untuk melek internet. "Memiliki kesulitan tapi dosen memang dituntut untuk menggunakan komputer dan internet sehingga harus belajar."

\section{Hambatan Penggunaan Internet di Kantor}

Ketika hampir semua pekerjaan akademik dan administrasi dosen berhubungan dengan internet, maka hambatan terbesar bagi para responden adalah sering down-nya akses. "Bila internet mati maka dapat menghambat pekerjaaan karena hampir semua pekerjaan bergantung pada koneksi internet." Namun bagi salah satu responden yang memegang jabatan sebagai Ketua Prodi dan dianggap paling sering berinteraksi dengan internet, hambatan terbesar yang paling riil sebenarnya bukanlah akses internetnya. Masalah akses, kemungkinan beberapa menit kemudian bisa diperbaiki. "Masalah terbesar ada dalam ketidakkonsistenan tujuan awal pengunaan internet, yaitu ketika berbenturan dengan birokrasi. Internet digunakan karena kemudahan aksesbilitas dan fleksibilitas waktu dan tempat. Namun hal ini menjadi aneh ketika atasan (birokrasi) mengatakan kalau dia akan menyetujui kegiatan pada waktu tertentu. Hal ini membuat internet jadi seolah-olah tidak dimanfaatkan secara maksimal, percuma, menjadi kontraproduktif. Sehingga penggunaan internet pada kenyataannya malah membuat kerja kita terhambat karena harus menunggu, contoh: pengajuan awal bulan, baru dicek atasan tengah atau akhir bulan."

Ketersediaan sarana prasarana teknologi dianggap tidak dibarengi dengan kesiapan sumber daya manusianya untuk bisa menjalankan program tersebut sesuai dengan visi awalnya. Hal ini diperparah juga dengan belum dimilikinya ema-il korporat oleh semua dosen. Ketika internet diharapkan mampu menghubungkan dan membagi informasi dengan cepat dan tepat kepada banyak orang, namun jika ternyata tidak semua mau membuka chanel-nya (baca: mengaktifkan ema-il korporatnya) berarti komunikasi seolah-olah hanya berjalan satu arah.

\section{PEMBAHASAN}

Hasil dari penelitian ini menunjukkan bahwa internet yang digunakan oleh dosen tidak didominasi oleh salah satu gender saja. Kedua gender memiliki pemahaman dan akses internet yang setara. Hal ini disebabkan karena responden adalah akademisi yang mendapatkan eksposure teknologi yang sama tingginya. Kegiatan akademis yang mewajibkan dosen mampu beradaptasi dengan perkembangan teknologi membuat mereka memiliki kapabilitas teknologi yang hampir setara. 
Walaupun demikian, terdapat sedikit perbedaan dalam hal pengalaman antargenerasi. Generasi $Y$ memiliki pengalaman lebih awal dalam berinteraksi dengan internet. Rata-rata pada usia 18 tahun mereka sudah mulai bereksperimen dengan internet. Sedangkan untuk generasi Baby Boomers dan $X$ lebih terlambat berkenalan dengan internet, yaitu ketika mereka mulai bekerja sebagai dosen. Pengetahuan tentang teknologi yang lebih awal membuat familiaritas terhadap teknologi lebih tinggi. Hal ini menyebabkan cara adaptasi terhadap teknologi baru menjadi lebih cepat.

Dalam hal tujuan menggunakan internet, semua responden memiliki kesamaan dalam hal bersosialisasi via media sosial. Facebook dan Twitter menjadi akun yang wajib dimiliki. $\mathrm{Hal}$ ini kemungkinan juga disebabkan karena kesamaan latar belakang sebagai dosen Ilmu Komunikasi yang mengharuskan melek terhadap teknologi komunikasi yang baru. Sedangkan untuk tujuan yang lainnya, perempuan dari generasi $X$ menggunakannya sebagai bisnis dan generasi $Y$ untuk belanja online. Walaupun demikian kedua gender dari generasi $Y$ juga memaksimalkan internet untuk tujuan akademis seperti bergabung dengan kelompok dosen di Facebook dan memiliki akun semacam scribd, academic.edu dan lainnya. Hal ini menunjukkan generasiYlebih mampu melihat kesempatan meningkatkan pengetahuan yang berkaitan dengan pekerjaannya dibandingkan generasi yang lainnya dengan memaksimalkan potensi dari membanjirnya informasi di internet.

Kedua gender berpendapat ema-il adalah sesuatu yang penting, baik untuk kepentingan pribadi maupun pekerjaan. Selain ema-il korporat UMS, semua responden memiliki akun Yahoo dan Gmail. Hal ini karena Yahoo mail muncul lebih dahulu (1997) dibandingkan Gmail (2004), yaitu masa ketika mereka mulai berkenalan dengan ema-il. Dibandingkan generasi yang lainnya, Baby Boomers adalah yang paling jarang mengecek ema-il. Baginya pesan singkat lebih efektif. Berdasarkan Pew
Research Center generasi Boomer memang lebih memilih mobile phone sebagai media komunikasi utama dibandingkan generasi $X$ dan $Y$ yang lebih memilih ema-il atau media sosial untuk menghubungi mereka.

Internet menjadi bagian penting bagi kegiatan dosen terutama dalam akademik dan administrasi. Semua generasi melihat adanya kontribusi yang besar dari programprogram berbasis internet yang ada. Namun, interaksi mereka dengan program tersebut lebih ditentukan dengan jabatan mereka di kampus. Selain Baby Boomers, semua responden memiliki jabatan struktural yang membuat mereka lebih sering menggunakan program tersebut.

Hambatan penggunaan internet disebabkan karena dua faktor, yaitu: faktor teknis dan faktor birokrasi. Faktor teknis adalah tidak stabilnya koneksi internet di kampus. Ketika hampir semua pekerjaan sebagai dosen maupun pejabat struktural membutuhkan internet untuk menyelesaikannya dan saat koneksi sering terganggu, maka pekerjaan juga akan terdampak. Sedangkan yang berkaitan dengan dengan birokrasi, responden perempuan $Y$ melihat tujuan efektivitas program dengan digunakannya internet ternyata tidak disertai dengan kesiapan manusianya.

\section{E. KESIMPULAN}

Teknologi telah mengubah cara manusia berkomunikasi. Manusia harus memahami perbedaan tiap generasi dan menggunakan pengetahuan tersebut untuk memahami perilaku terhadap teknologi. Dalam penelitian ini terlihat bahwa penggunaan internet di UMS tidak dipengaruhi oleh faktor gender melainkan lebih kepada faktor generasi. Hal ini disebabkan kedua gender memiliki lingkungan pekerjaan yang mengharuskan mereka mengakses teknologi yang sama.

Umur memiliki peran dalam perbedaan penggunaan teknologi. Generasi yang lebih muda menggunakan internet lebih untuk optimalisasi diri dan kemudahan 
berkomunikasi. Khususnya generasi $Y$ melihat teknologi sebagai bagian yang penting bagi kehidupan dan pekerjaan mereka. Mereka cenderung mudah untuk merangkul, berinteraksi, dan beradaptasi secara cepat dengan teknologi baru. Sedangkan generasi yang lebih tua menggunakan internet untuk pemenuhan kewajiban yang berkaitan dengan pekerjaan. Mereka lebih familiar dengan telepon genggam dibandingkan gadget yang lainnya.

\section{F. SARAN}

Penelitian ini hanya berfokus pada peran gender dan generasi pada penggunaan internet oleh dosen dalam satu program studi. Untuk penelitian selanjutnya, sampel bisa diperbanyak untuk melihat pola penggunaan internet oleh dosen yang lebih luas. Penelitian selanjutnya juga bisa diarahkan untuk melihat pola penggunaan internet berdasarkan life stages (antara dosen yang sudah menikah dengan yang belum atau antara dosen yang sudah memiliki anak dengan yang belum). Hasil penelitian ini diharapkan mampu memberikan masukan bagi pihak universitas dalam membuat dan mendesain program berbasis internet untuk dosen agar efektivitasnya dapat maksimal.

\section{DAFTAR PUSTAKA}

Babbie, Earl R. 1995. The Practice of Social Research: $7^{\text {th }}$ Edition. USA: Wadsworth Publishing Company.

Berg, Bruce L. 1995. Qualitative Research Methods for Social Sciences. USA: Alyyn \& Bacon.

Creswell, J.W. 2009. Research DesignL Qualitative, Quantitative, and Mixed Methods Approaches $3^{\text {rd }}$ Edition. Thousands Oaks. CA Sage Publication.

Helsper, Ellen. 2010. Gendered Internet Use Across Generations and Life Stages. Social Science Computer Review. Sage Publications. http://eprints.Ise.ac.uk/28401/

Kriyantono, Rachmat. 2010. Teknik Praktisi Riset Komunikasi. Jakarta: Kencana.

Munusamy, Komathi dan Maimunah Ismail. 2009. Influence of Gender Roles on Internet Usage Pattern Among Academicians. The Journal of International Social Research. Volume 2/9 Fall.

Ramasubbu, Suren. 2015. From Gen X to Y and Z: Technology and The Generation Gap. huffingtonpost.com

Rizvi, Syed Asad Abbas. 2010. Effect of Internet on The Academic Performance and Social Life of University Students in Pakistan. Jounal of Education and Sociology, Dec 2010. ISSN: 2078-032x.

Royal, Cindy. 2007. Framing the Internet: A Comparison of Gendered Spaces. Social Sage Publications. http://ssc.sagepub.com/content/26/2/152

Selwyn, Neil, Stephen Gorard, dan John Furlong. 2005. Whose Internet is it Anyway? Exploring Adults' (Non) Use of Internet in Everyday Life. European Journal of Communication. Sage Publication Vol.20 (1): 5-26.

Singh, Supriya. 2001. Gender and The Use of Internet at Home. New Media Society Journal. Sage Publications. http://nms.sagepub.com/content/3/4/395

Thanuskodi, S. 2013. Gender Differences in Internet Usage Among College Students: A Comparative Study. Library Philosophy and Practice (e-journal). Lincoln: Nebraska. 
Weiser, Eric B. 2004. Gender Differences in Internet Use Patterns and Internet Application Preferences: A Two-Sample Comparison. CyberPsychology and Behaviour Journal Vol. 3 Issue 2: July 5, 2004.

Yusuf, A. Muri. 2014. Metode penelitian Kuantitatif, Kualitatif, dan Penelitian Gabungan. Jakarta: Kencana. 